\title{
THE STRENGTH OF LECTURER INTERPERSONAL COMMUNICATION IN THE IMAGE FORMATION OF MARKETING COMMUNICATION STUDENTS, BINA NUSANTARA UNIVERSITY
}

\author{
Dina Sekar Vusparatih \\ Marketing Communication Department, \\ Faculty of Economic and Communication, Bina Nusantara University \\ Jl. K.H Syahdan No.9, Palmerah Jakarta Barat, 11480 \\ dinasekar@yahoo.com
}

\begin{abstract}
The good relations would have a direct impact on the impression created in the students' perception. The existence of a positive image of the lecturers would certainly go hand in hand with the creation of a positive image for the majors and the university eventually. This article used case study with qualitative method. The interview was the main tool of data collection. Researchers chosea few students who are still studying during the research but have been studying for few years (3 years or 6 semesters) as the resources/interviewee. It finds that indirectly style and interpersonal communication skills of lecturers can affect image formation majors and university.
\end{abstract}

Keywords: lectures, interpersonal communication, image formation, marketing communication

\section{INTRODUCTION}

The word "imaging" of recent years becomes a popular word. Not only in academic circles, but also in public officials. This word begins to be commonly used the word. The growth of imaging word in today's society is better known in the political context. Imaging is understood as meaning a person's attempt to win the hearts and trust of society in order to be elected to parliament or elected in local elections (elections), or who actually was being discussed in the presidential election in 2014.

Imaging is an attempt to form the image. The image is the reflection of the reality of an organization or individual in the eyes of its constituents (Argenti, 1998). The image of an organization or the same individual may vary in the presence of different constituents. Organizations or individuals who have a good image usually have a loyal constituency. This is due to lack of trust. The image directly related to confidence. Having a positive image has huge implications for an institution. This is because the image will generate attitudes, opinions, comments, or behavior (Nova, 2011). A good image will bring up the confidence anyway. Just look at the various products that have a good image. Whatever the price goes up, it is still purchased by the public. This is because people believe that the product is very beneficial for them and with a guaranteed quality for a long time.

Unfortunately, the role of images in an organization or institution is huge, especially in building public trust that is not realized by many people. Image only much in demand by the politicians. Even so, there is little change in the educational institutions which incidentally also produces a service that is service-producing academic level graduation. Some private schools and private universities mainly in Jakarta has showed an effort to establish a good image. Competition 
among educational institutions, especially in the private sphere is very high. As the data released by Kemendikbud in 2008. The data shows that in seven years there has been a growth in the number of Universities for Public and Private by $13 \%$ and 58\%. Meanwhile, in terms of a number of students in seven years, generally the number of students that only about 924,000 students in 2000, grew up to 2.6 million people in 2008 (Pikiran Rakyat, 2010). Not surprisingly, the education industry, in turn, has a special attraction for those who have big capital.

Universitas Bina Nusantara (BINUS) is one of the many private universities that is well known has a good image. 30 years is a long time in building the image. BINUS are very familiar with the quality of graduates Information Technology (IT). The opening of the faculty for the other majors is a quite risky step in developing a successful business, but it has been proved that BINUS has opened a new department with the reception of a high number of new students.

One of the new department is opened by BINUS is majoring in Marketing Communication (Marcomm). It is officially opened in the academic year 2007/2008 and directly opened classes for 320 students. Marcomm department is immediately soared on the number of admissions of students compared with other majors in BINUS. Within four years, Marcomm department manages to have 1535 students (Source: Student Information Service of Bina Nusantara University). Moreover, if we see the survey of image formation, the position of the Marcomm department BINUS is the fifth position of the whole colleges that have Communications Programs (Advertising, Public Relations, Marketing Communication, Mass Communication and Communication Design) in term of the bachelor degree. This survey is viewed from four categories; they are reputation, quality graduation, a match between the cost of the value or benefits received, and equality with quality higher education abroad (Aruman, 2011).

Alumni are the key person to give the recommendation for developing a good image. Alumni will certainly experience stories and feelings when studying for four to five years to the younger, relatives, coworkers, or whomever they might have children later. The students who are now attending college will tell you the same thing. The story most often heard about the tutor's course and lecturer.

Teaching and learning activities always involve interaction between lecturer and students. How lecturer teaches and interacts with students is an important point in shaping the image of the university. A well-known university will be good not only for the quality of the alumni but also because of the quality of the lecturers. The lecturer will produce good alumni. Qualified lecturers are not only because they are coming from the top university with a high GPA. Lots of degrees do not guarantee a lecturer will be a good lecturer. We meet a lot of smart people who actually experienced another but having the problem in delivering knowledge to others. Students cannot easily understand the explanation given. Though an understanding of the content and concept that given by the faculty is the key to students' success. This is where the ability to communicate with their lecturers as an important factor.

According to Devito (1996), psychological element is the interpersonal communication that has a variety of purposes, namely to learn, to connect, to influence, to play and to help. Interpersonal communication allows us to learn, to understand better about the world, various events and others. Although we can obtain information from the media, most likely we will discuss again the information through interpersonal communication. Even beliefs, behaviors and values that we have are much more influenced by the impact of interpersonal communication than from the media or forum formal education.

Based on the background of the problems above, this study follows formulate problems, how interpersonal communication lecturer in shaping a positive image for the Department of Marketing Communication at Bina Nusantara University and why interpersonal communication skills of lecturer can support the formation of a positive image. The following Table shows the state of art this study. 
Table State of the Art

\begin{tabular}{|c|c|}
\hline Author & Summary \\
\hline $\begin{array}{l}\text { Formation of Positive Image In } \\
\text { Higher Education Institutions/Dina } \\
\text { Sekar Vusparatih (2012) }\end{array}$ & $\begin{array}{l}\text { The image formation for a university is very important as it supports the } \\
\text { growth of all its faculties. The positive image which has been owned by the } \\
\text { university to support and assist the newly established majors. } \\
\text { Strategy in building the image of the university is not the work of the } \\
\text { Public Relations division, but also the active participation of all elements of the } \\
\text { campus. In addition, the target audience in building the image is not only students } \\
\text { but also prospective students, parents, other companies, and alumni.Step-by-step } \\
\text { strategies of forming a positive image in the Department of Marketing } \\
\text { Communication, University Bina Nusantara are: } \\
\text { 1. The strength of the big names } \\
\text { 2. Selection of study program } \\
\text { 3. Selection of the name of the majors } \\
\text { 4. A good internal management } \\
\text { 5. The Role of Public Relations } \\
\text { 6. Trust from parents } \\
\text { 7. Positive Publications } \\
\text { 8. Curricula and lecturer } \\
\text { 9. The development potential of students and alumni }\end{array}$ \\
\hline $\begin{array}{l}\text { Personal Role In Establishing } \\
\text { Communication Between Self } \\
\text { Concept Students/I Deaf in SLB-B } \\
\text { Karya Murni - Terrain/Oloan } \\
\text { Hendra Ricki Silalahi (2011) }\end{array}$ & $\begin{array}{l}\text { Counseling Service counselor and student/I Deaf plays a major role in } \\
\text { shaping a positive self-concept students/I deaf. This occurs because of the } \\
\text { atmosphere counseling close and intimate communication.The study's findings also } \\
\text { indicate that the service counseling that has been given to the student/I deaf is good } \\
\text { enough. It is seen that the students/I deaf showed myself a reasonable concept. } \\
\text { They realize a state of disability, but the situation does not weaken their handicap. } \\
\text { Effective interpersonal communication had led to the formation of the concept of } \\
\text { the student/I deaf as open to the experience, not to be defensive, careful awareness, } \\
\text { self-esteem unconditionally, and can establish a harmonious relationship with } \\
\text { others. }\end{array}$ \\
\hline $\begin{array}{l}\text { Effective Interpersonal } \\
\text { Communication: A Practical Guide } \\
\text { To Improve Your Life }\end{array}$ & $\begin{array}{l}\text { Effective interpersonal communication is necessary to negotiate the } \\
\text { challenge of everyday living, whether in your personal and professional life. } \\
\text { Because human beings are complex and each individual bring his or her own set of } \\
\text { internal variables to every situation, the possibilities of interactional outcomes of } \\
\text { any given communication can be exponential. }\end{array}$ \\
\hline $\begin{array}{l}\text { Kathleen A. Vertino, DNP, } \\
\text { PMHNP-BC, CARN-AP (2014) }\end{array}$ & $\begin{array}{l}\text { Although much has been written regarding workplace violence, practical } \\
\text { strategies for addressing the mechanism of effective interpersonal communication } \\
\text { are lacking. In order to address this, we need frank, open conversations regarding } \\
\text { how our personal internal variables affect our interpretation of the world as we see } \\
\text { it. }\end{array}$ \\
\hline
\end{tabular}

This study uses some of the theories and concepts as a guide and foundation, such as interpersonal communication, social penetration theory, and the image. Interpersonal communication is a process of exchange of meaning between people who are communicating. Understanding the process of referring to the changes that take place constantly. Interpersonal communication is also an exchange, namely actions convey and receive messages on a reciprocal basis. While the meaning, which is something that is exchanged in the process, is a common understanding among those who communicate with the messages used in the communication process (Sendjaja, 1994).

Meanwhile, according to Little John, interpersonal communication is communication between people, usually face-to-face and personal (Littlejohn, 2005). Characteristics inherent in the process of interpersonal communication are (1) Interpersonal communication starts with self; (2) Interpersonal communication is transactional; (3) Interpersonal Communication includes aspects message content and interpersonal relationships; (4) Interpersonal communication requires physical proximity between the parties to communicate; (5) Interpersonal communication involving the parties interdependent with each other in the communication process; (6) Interpersonal communication cannot be changed or repeated (Pearson, 1983). 
The elements in Interpersonal Communication are (1) Source or communicator, Interpersonal communication involves at least two people. (2) Encoding and decoding. Encoding is action to produce messages, while decoding is the action to understand the message. (3) Competence or the capability to communicate effectively. These capabilities include knowledge, decency in controlling the volume of sound, touch, and physical action. (4) The message, it can be through hearing, sight, touch, smell, taste, or a combination of them. Interpersonal communication does not have to happen orally but can be in other forms. (5) The channel is media to deliver the message. (6) Noise/disruption, there are three types of disorders: physical, psychological, and semantic. (7) Context, there is a fourth dimension in the context of the communication process, namely the physical context, the context in which temporary, psychological, social context and cultural context. (8) Interest. (9) Effects. (10) Ethics.

Basic strength is present in all interactions and interpersonal relationships. Strength/power presents in all relationships and all reciprocal communication. There are 6 types of powers, namely: (1) Strength/power granted; (2) Strength/power legitimized; (3) Strength/power to give a gift; (4) Coercive force; (5) Strength/power expert; (6) Strength/power information or persuasive. While, according DeVito (1996), the communicating strength can be seen from the power to speak, the power of non-verbal and the power of hearing.

Another theory applies in this study is social penetration theory. This is a theory about the development of relations associated with systemic changes in communication. In communicating in a relationship, there are two dimensions, breadth, and depth in discussing a topic (Littlejohn, 2005). This theory identifies several stages in a relationship, they are (1) Stage orientation, for example when the talks begin a short, simple, and about anything; (2) The exploratory phase of affective, for example when it begins to show personal expression on general topics such as on government and education. This stage is the stage of friendship which normally would not be much further; (3) Affective stage, namely when it starts discussing personal issues. Criticism and arguments start there. Have started there and hug intimate touch; (4) Stable phase, for example when the relationship reaches the level of sharing and knowing their emotional reactions; (5) Phase anti-penetration, is when the relationship begins to disintegrate and cost than benefit. The relationship will end (Littlejohn \& Foss, 2009).

Lastly, the theory uses in this study is the image. According to M Wayne De Lozier, the image will be visible or formed through a process of receiving a physical (sensory), entered into a strainer attention (attention filter), and from there to produce messages that can be understood or seen (perceived message), which later turns into perception and finally the image (Theresia, 2001 ).

\section{METHODS}

Research interpretative learns the meaning of social action, not only from external but observing attitudes. Social actions carry out for no purpose and have a very subjective meaning. Social reality is not just there and ready to be found as the thought of a positivist paradigm, but the social reality is the result of human acceptance and men that feel and interpret (Newman, 1997). The approach used in this study is a qualitative approach. This approach allows researchers to know personally the object of study and look at the object of research to build their understanding of the world. (Bondan \& Taylor, 1975).

This study uses the case study method. Case study method with qualitative research approaches is like a coin. Both are always intertwined. In the case study method, the researchers will have so much information and try to understand it in depth so as to sink into them, which in turn creates intimacy and closeness between researchers with the life or culture of that investigation. 
Looking for patterns of life, actions, and words of the object under study to then are interpreted as a whole (Newman, 1997). Data collection techniques in this study are interviews and participant observation. Depth interview will be the main data collection techniques in this study. In-depth interviews are aimed not only to ask questions but a sense of the life experiences of others to capture the meaning given investigators interviewed the subject on his experience (Raco, 2010).

In this study, the interview is the main tool of data collection. Researchers chose few students who are still studying during the research but have been studying for few years (3 years or 6 semesters) as the resources/interviewee. The reason for choosing those students in the third year is because they have already used to the campus routine, used to lecturing, known lots of lecturers, mature enough to decide their action facing other people specially lecturer, and mature enough to assess and evaluate appropriate action or not in student and lecturer relationship. Moreover, those students are about leaving the campus in another one year, so that they have a very big potential to decide whether they will recommend BINUS University to their younger family or friends. They will be as alumni soon. They will become the brand ambassador for BINUS University.

In addition to interviews, data collection techniques used was observation. Participant observation is observing objects with direct live together, feel and be in life activity the object of observation. As the last data collection, techniques is literature. While the literature is the data collection techniques by searching the supporting data, theory, and understanding of a concept, of scholarly books or resources related to the problem that is being investigated, and then analyzed (Theresia, 2001).

One characteristic of the qualitative approach is the use of descriptive data analysis techniques. Techniques descriptive data analysis is research that aims to describe systematically the facts or characteristics of a particular population or a particular field, whether it be the state, issues, attitudes, opinions, conditions, procedures or systems factual, and accurate. The researcher as an observer, just creates a category of behavior, noting the symptoms, not set or manipulated variable. Descriptive research is more focused on observation and scientific atmosphere (Soewadji, 2012). The unit of analysis in this study is students majoring in Marketing Communication University of Bina Nusantara year 2010 to 2011.

\section{RESULTS AND DISCUSSIONS}

It is undeniable that the communication process occurs in all aspects of life and different contexts and levels. Likewise, in the context of the lecture where there is the intense interaction between lecturer and students. Teaching in the classroom is not the only form of communication between lecturers and students. After hours of teaching communication process is still ongoing and covers a range of topics. As stated by the speakers, the communication between lecturers and students often occur after lecturers teach communication or by chance bumped into on-campus or had promised to discuss something outside of teaching hours. As stated by speakers Nabila. It usually happens in lecturers' room and the absence of class hours. The topic is about the lecture and set the time that I (Nabila) am becoming one of the students' leaders. This is also supported by the speaker Billy that the communication process persists beyond teaching hours. According to Billy, typically speaking when completed lecture hours or during breaks, and talk about subjects that are taught, the discussion about the thesis and the guidance, the world of work, and talk about other lecturers teaching style is unique, humorous, and even boring.

From both a resource statement above, it can be concluded that there is a process of communication outside the classroom after teaching hours. Talking between lecturers and students 
also take place after the completion of teaching. Not stopping there, the conversation outside of teaching hours also occurs not only on campus but also outside the campus area wherecommunication is done by using the media. This is also explained by the speakers.

At this time, there are a variety of media that can be used to communicate between two people or in groups. Call it the Blackberry Messenger (BBM), Whats App (WA), Line or email for a message that is quite a lot. All of the media is also used as a mean of the communication between students and professors. The sources, Reny, also say the same thing. Renny said that sometimes the communication happens via text messages, line, Whats App, or blackberry messenger. Other resource persons namely Amanda also said the same thing should take place one-way communication. According to Amanda, there is no talk between professors and me outside of class hours. But the professor does often send me and another student an email. The email is about the current topic. On the other speakers, communication uses media lasted more active. As stated by the informant Billy that Whats App, line, and email consultation is usually a matter of lecture. But there are also speakers who rarely use the media but still no communication outside teaching hours. From four statements by the informants can be said that communication outside teaching hours still occurs between students and lecturers in spite of using the media. But the using of media is different objectives and styles.

Apart from the direct talks or through the media, it is concluded that communication between faculty and students outside of teaching hours is going on all the students. The level of public communications that conducted by a lecturer when he/she taught is later changed into interpersonal communication when he is in communication with the student after finished teaching or outside teaching hours. As stated by Sendjaja (1994), interpersonal communication is a process of exchange of meaning between people who are communicating. Understanding the process refers to the changes that take place constantly. Interpersonal communication is also an exchange, namely actions convey and receive messages on a reciprocal basis. While the meaning that exchanged in the process, it is a common understanding among those who communicate with the messages used in the communication process (Sendjaja, 1994).

Interpersonal communication occurs for a particular purpose of the perpetrators. According to Sendjaja (1994), people need interpersonal relationships primarily for two things: the feelings and dependency. Feelings refer to a relationship that is emotionally intense. The addiction refers to the instrument interpersonal behavior, such as requiring assistance, needing approval and seeking nearness. Furthermore, in addition to the needs of friends, people also need each other to maintain the interest alive. The complexity of today's world makes us dependent on each other. The result is that we feel the need to share and cooperate (Sendjaja, 1994).

From the second statement from Sendjaja (1994), it is not surprising if the communication between students and professors outside of teaching hours is a form of interpersonal communication. Where the purpose of this communication is the interdependence and the need in the context of the lecture or even broader and deeper. Pearson (1983) has explained the characteristics of interpersonal communication, namely: (1) Interpersonal communication starts with self; (2) Interpersonal communication transactional; (3) Interpersonal communication includes aspects message content and interpersonal relationships; (4) Interpersonal communication requires physical proximity between the parties to communicate; (5) Interpersonal communication involving the parties interdependent with each other in the communication process; (6) Interpersonal communication can not be changed or repeated.

From these six characteristics of this, some of the occurred communications will meet one or two or even all when the communication between students and lecturers. This is consistent with the statement of sources, Billy, who stated that he usually talks face to face and the atmosphere of the class was quiet, and generally speaking sits face to face in the classroom, according to the situation after the completion of the class is more relaxed. Billy statement shows their physical proximity and 
begins with their self. The same process occurs in other sources, Renny. At that moment, she is usually sitting opposite off-campus, academic side by side, sometimes while the road leading out of the campus. All three speakers clearly demonstrate the situation when communicating with lecturers by face to face; there is the physical proximity and transactional. Interestingly, there is a statement from Amanda, the other resources, that describes the same situation, but it actually does not what the speaker wants that to happen. As the following statement by Amanda,

\begin{abstract}
"Sometimes while standing or sitting side by side. Just more often stood face to face, that too in the area around the campus and not in the classroom after teaching. If she met in class and definitely no chair to sit down or if the lecturer was looking at me she could walk toward me (sometimes I tried to avoid)."
\end{abstract}

There is a picture of the situation that the speaker does not want interpersonal communication occurs when accidentally met, yet because respect of students to lecturers so she/he eventually undergoes such communications. From the statement of the informants and description of the existing situation, it can be said that indeed the case interpersonal communication between students and lecturers outside of teaching hours is either intentionally or unintentionally. Forms of interpersonal communication ensue with their physical proximity between communicators, like sitting face to face or sit side by side. The distance is not too far away, but also in an intimate level. Clearly, all three illustrate that the distance between students and lecturers are not too far or may be close enough when communication occurs.

After clearly discussed that interpersonal communication happens between students and lecturers outside of teaching hours, and then the further discussion is the stages of the process from the perspective of interpersonal communication Social Penetration Theory. The next question is there a connection of the theory with practice interpersonal communication occurs in the Department of Marketing Communication? Social penetration theory is a theory about the development of relations associated with systemic changes in communication. In communicating of a relationship, there are two dimensions in discussing this topic; breadth and depth. In this theory, Littlejohn and Foss (2009) have explained that there are five stages in a relationship, namely: (1) Stage orientation when the talks begin a short, simple, and about anything; (2) The exploratory phase of affective is when it begins to show personal expression on general topics such as on government and education. This stage is the stage of friendship which normally would not be much further; (3) Affective stage, namely when it starts discussing personal issues. Criticism and arguments start there and hug intimate touch; (4) Stable phase, is when the relationship reaches the level of sharing and knowing their emotional reactions; (5) Phase anti-penetration is when the relationship began to disintegrate and cost than benefit, and it will cause the relationship ends.

Obviously, we have already passed the first stage in the process of communication between lecturer and students in the Department of Marketing Communication, Bina Nusantara University. The stages that contain simple conversation to the topic of irregular has been more focused as if the conversation had focused on the issue of lectures and even some have started to the affective stage which is discussing personal issues. But to get to the stage of affective communication between students and lecturers, it usually starts from the stage and exploration affective orientation. Instead, there are also students who speak quite freely but limit the topic only at the exploratory stage affective. It is not uncommon that the lecturers themselves begin to move on stage to the affective. Student responses vary when lecturer do this. No one is following the process but not provide followup, but some are choosing to stop the exploration stage only affective.

The four resource statements can be said that they experienced stages in social penetration theory, but each has his own choice in determining the depth of the topic. Proceeding to the further stages is determined not only by the students but also by the lecturers that want to continue to the deeper stages. Two sources have said that there is also a lecturer who loves to tell about his family, 
though it is still considered within the normal stage. In the context of the use of the media, it appears that student is quite flexible in use emoticons when talking with the lecturer even though they use standard emoticons such as smiling or happy. This flexibility is also felt when talking face to face.

The second speaker of the statement indicates the level of discretion when speaking with the lecturer. The feeling of talking as a friend and a short distance indicates the degree of intimacy and discretion when the interaction occurred. This shows that indeed interpersonal communication that occurs between the two because of the stages in the social penetration theory going on inside.

Having previously discussed interpersonal communication and social penetration theory phases in the interaction between students and lecturers in the Department of the Marketing Communication University of Bina Nusantara, it will be discussed whether in the form of the communication relating to the department's image. Assessment of the lecturers would lead to an assessment of the majors that based on multiple components. But one of them is how the two main actors interact in a campus as students and lecturers. The process of communication between the two is not only taking place in the classroom when lecturers are teaching but also on the outside of teaching hours and the process continues. Various forms and communication processes that occur outside of teaching hours appear with different extent. But one thing for sure is the communication process continues and becomes routine. Therefore, the communication process becomes student assessment against the majors, because even though the department itself that becomes the first person or element recruits and trains the lecturers.

This assessment is the one that forms the image of the majors. According to Lozier (as cited in Theresia, 2001), the image will be visible or formed through a process of receiving a physical (sensory), entered into a strainer attention (attention filter) and from there to produce messages that can be understood or seen (perceived message), which later turns into perception and finally the image. The image is formed through a process of receiving a physical (the five senses). This sentence clearly states that anything related to the five senses will eventually form the image. Communicating is a process that involves full sensory. Talking, seeing, hearing, and touching are four activities in the communication process. In the fourth interpersonal communication activities that take place simultaneously and the same happens between two people as well as within a short distance so as to allow both attentions to detail. Thus directly or indirectly the process of interpersonal communication between students and professors affect the image formation majors on college campuses.

Almost all the speakers said that the way of communicating the lecturer in the form of interpersonal communication is affecting the image formation majors. All three speakers can be concluded that according to their interpersonal communication established between lecturers and students could assist departments in shaping a positive image if it goes in a positive way as well. But it all depends on the lecturers themselves in building the interpersonal communication. Then interpersonal communication as what is expected of students to form a positive image for the majors. According to some sources stated that there is a way of communicating lecturer can influence their votes against the majors. The students still want their interpersonal communication occurs with lecturers, but they hope that the communication process is running relaxed and open, while the lecturer is still maintaining his/her authority as a lecturer.

\section{CONCLUSIONS}

Interpersonal communication cannot be denied occurred outside of teaching hours between lecturer and students. This form of communication occurs through stages of social penetration that each phase takes place differently depending on the actors decide to where the stage ends. Due to the 
communication process that takes place simultaneously and continuously, it is eventually formed the image of the student to the majors. Communicating with lecturers as well as communicating with the majors because lecturers are recruited and nurtured by the department. Therefore indirectly style and interpersonal communication skills of lecturers can affect image formation majors.

The lecturer is not supposed to cover up to communicate with students outside teaching hours. But the forms of interpersonal communication that are formed should be undertaken with caution, because of the nature of communication that can end in intimacy. The relationship between lecturer and student is sensitive and under lots of ethics and norms. Students expect lecturers can be more relaxed in communicating with students, but lecturers are expected to maintain the dignity and demeanor as a lecturer. A good image of the department will help advance the department where one of them is to the marketing process and the sustainability of the university.

\section{REFERRENCES}

Argenti, P. A. (1998). Corporate Communication. New York: McGraw-Hill.

Aruman, E. (2011, November $\left.16^{\text {th }}\right)$. Marketing Untuk Semua. Retrieved November $5^{\text {th }} 2014$ from edhy-aruman.blogspot.co.id.

Bondan, R., \& Taylor, S. J. (1975). Introduction to Qualitative Research Methods. New York: WileyInterscience.

Devito., \& Joseph, A. (1996). The Interpersonal Communication Book. New York: Longman.

Littlejhon., \& Stephen, W. (2005). Theories of Human Communication. Canada: Thomson Learning.

Littlejhon., Foss, S. W., \& Karen, A. (2009). Encyclopedia of Communication Theory 2. USA: Sage

Newman, L. W. (1997). Social Research Methods Qualitative and Quantitative Approaches (4 ${ }^{\text {th }}$ Ed). USA: A Pearson Education Company.

Nova, F. (2011). Crisis Public Relation. Jakarta: PT Gramedia Widiasarana.

Pearson, J. C. (1983). Interpersonal Communication; Clarity, Confidence, Concern. USA: Scot Foresman.

Pikiran Rakyat. (2010, April 8). Persaingan PTS Semakin Ketat. Retrieved November $5^{\text {th }} 2014$ from http://www.pikiran-rakyat.com/pendidikan/2012/09/15/203549/uu-no-122012-buat-kondisipts-semakin-terjepit.

Raco, J. R. (2010). Metode Penelitian Kualitatif. Jakarta: PT Gramedia Widiasarana.

Sendjaja, S. D. (1994). Teori Komunikasi Materi Pokok Modul 1-9. Jakarta: Universitas Terbuka

Silalahi, O. H. R. (2011). Peranan Komunikasi Antar Pribadi Dalam Membentuk Konsep Diri Siswa/I Tuna Rungu di SLB-B Karya Murni. Medan: Fisip Universitas Sumatera Utara.

Soewadji, J. (2012). Pengantar Metodologi Penelitian. Jakarta: Mitra Wacana Media. 
Theresia, C. (2001). Public Relations Citibank Dalam Membangun Citra Yang Positif-Skripsi Tidak Diterbitkan. Jakarta: FISIP UI.

Vertino, K. A. (2014). Effective Interpersonal Communication: A Practical Guide to Improve Your Life. The Online Journal Of Issues in Nursing, 19 (3).

Vusparatih, D. S. (2012). Pembentukan Citra Positif Di Lembaga Pendidikan Tinggi (Studi Kasus Jurusan Marketing Communication Universitas Bina Nusantara) (Master's Thesis). Available from Pasca Ilmu Komunikasi Prof Dr Moestopo, Jakarta. Beragama. 